\title{
Anatomical Notes on the Attachment of the Diaphragm to the Abdominal Viscera Particularly to the Stomach in Bovine Fetuses and Neonates
}

\author{
Kôsaku Fukaya*, Ietoshi Kaneko, Masao Asari, \\ Yasunobu EGuchI and Yutaka Kano** \\ Department of Veterinary Anatomy, Azabu Veterinary \\ College, Sagamihara-shi 229
}

(Received May 7, 1979)

\begin{abstract}
In ruminants such as cattle, the way of attachment of the diaphragm to the abdominal organs may have an important meaning to rumination. In the present study, by the use of bovine fetuses and neonates, the way of attachment particularly to the stomach was examined by observation of formalin-fixed materials and resin-casts of the alimentary canal along with the casts of thoracic and abdominal cavities. The caudal end of esophagus and the cardia were supplied mainly with muscular fibers from the right crus of the diaphragm. Main attachments to the stomach were those by muscular tissues from the left crus. The areas of the diaphragmatic attachment to the stomach showed parallel limbs, both dorso-caudal ends of which were connected like an inverted V-shape with a frontal view. The right limb of this inverted V-shape covered the cardiac region in association with muscular fibers from the right crus, extending backward to the dorsal surface of the cranial sac of rumen to reach the right dorsal surface of the dorsal sac of rumen. The left limb started from the dorsal surface of reticulum, extending backward to the left dorsal surface of the dorsal sac of rumen to reach the spleen. The connecting part of the both limbs was very thin in fetuses, becoming thicker, wider and more tight in neonates. Between these two limbs and under the bridge-like connection of both limbs, a blind tunnel-like space lined by a serous membrane with loose connective tissue was located to leave the so-called "Atrium ruminis" (Nickel et al.) always free from the diaphragm. The foregoing observations may be helpful in considering the mechanism of rumination.
\end{abstract}

Jap. J. Zootech. Sci., $50(11): 811-820,1979$

According to its original attachment, the diaphragm is divisible into three parts, lumbar, costal and sternal. It has a broad tendinous portion in its center, constituting a membranous part of densely textured connective tissue. The diaphragm is perforated by three foramina, the hiatus aorticus, the foramen venae cavae and the hiatus esophageus. The diaphragm serves not only as a partition of the thoracic and abdominal cavities, but also as a muscular wall playing a great role in respiration as well as in covering and holding the abdominal viscera.

Since muscles around the hiatus esophageus have been considered to play a role in rumination of the cattle as suggested by NICKEL et al. ${ }^{1}$, the exact relation of the

* Present address: Shinsei-Shiryo Co., Setagaya-ku, Tokyo 156.

** Request of Reprints to Dr. Yutaka Kano, Department of Veterinary Anatomy, Azabu Veterinary College, Sagamihara-shi, 229.

Jap. J. Zootech. Sci., 50 (11): 811-820 
diaphragm to the stomach should be also examined in association with rumination mechanism. Some textbooks ${ }^{1-3}$ describe briefly that in ruminants, the lumbar part of the diaphragm composes a specific structure related to the cardia of the stomach. Nevertheless, no more exact information is available as regards to what area and to what extent in the abdominal viscera the diaphragm attaches.

The present study, therefore, was undertaken to elucidate in more detail the area and extent of attachment of the diaphragm to the abdominal viscera especially to the stomach by examination of formalin-fixed materials and of resin-casts of the alimentary canal together with the casts of abdominal and thoracic cavities of bovine fetuses and neonates. The casts of abdominal and thoracic cavities were advantageous to clarify the range of the diaphragmatic attachment to the neighboring viscera with a negative image of the diaphragm.

\section{Materials and Methods}

Eight bovine fetuses, $20-35 \mathrm{~cm}$ in C.R. L., obtained from the Tama Meat Inspectors Station, and nine newborn calves, within 3 days after birth, obtained from owners in the environs of our College were used in this study.

Some animals were used for observation under the formalin-hardened condition. A formalin-gelatin solution was perfused through a catheter introduced into the right carotid artery and drained from the umbilical arteries in order to complete the hardening of the internal organs via vascular route. Thereafter, the same solution was injected into both the thoracic and the abdominal cavities to supplement the hardning of visceral organs. At an appropriate time when the visceral organs appeared to be

\section{Explanation of Figures}

Fig. 1. Frontal view of a cast of the abdominal cavity of a bovine fetus, $27 \mathrm{~cm}$ in C.R.L. The W-shaped space seen on the dorsal side shows the area of attachment of the diaphragm to the abdominal viscera. A, margin for the liver; $B$, margin for the esophagus and cardia. C, margins for the dorsal sac of the rumen; D, margin for the spleen. $\times 0.8$.

Fig. 2. Frontal view of a cast of the abdominal cavity of a newborn calf, $100 \mathrm{~cm}$ in C.R.L. The space on the dorsal side shows a roughly shaped $W$, representing the area of attachment of the diaphragm to the abdominal viscera. The labels of A, B, C and D stand for the same margins respectively as shown in Fig. $1 . \times 0.2$.

Fig. 3. Dorso-frontal view of formalin-hardened viscera of a fetus of $30 \mathrm{~cm}$ in C.R. L., with attached areas of the diaphragm left in situ by severing along the attaching edge to the abdominal organs. The attached areas were painted blue from the thoracic side in the original specimen. In order to make these areas clear to the readers, the areas are bordered by black lines. A portion striped with white lines is that part which was a thin membrane of the diaphragm. For details, refer to the text. L, the right lobe of the liver; E, caudal end of the esophagus with the cardiac region; $R e$, the reticulum; $\mathrm{Sp}$, the spleen; Ru, the rumen. $\times 0.7$.

Fig. 4. Dorso-frontal view of formalin-hardened abdominal viscera of a newborn calf of $95 \mathrm{~cm}$ in C. R. L., with attached areas of the diaphragm left in situ by severing along the attaching edge to the abdominal organs. The attached areas are also bordered by black lines, in order to make them clearer to the readers. For abbreviations, refer to Fig. 3 , $\times 0.3$. 

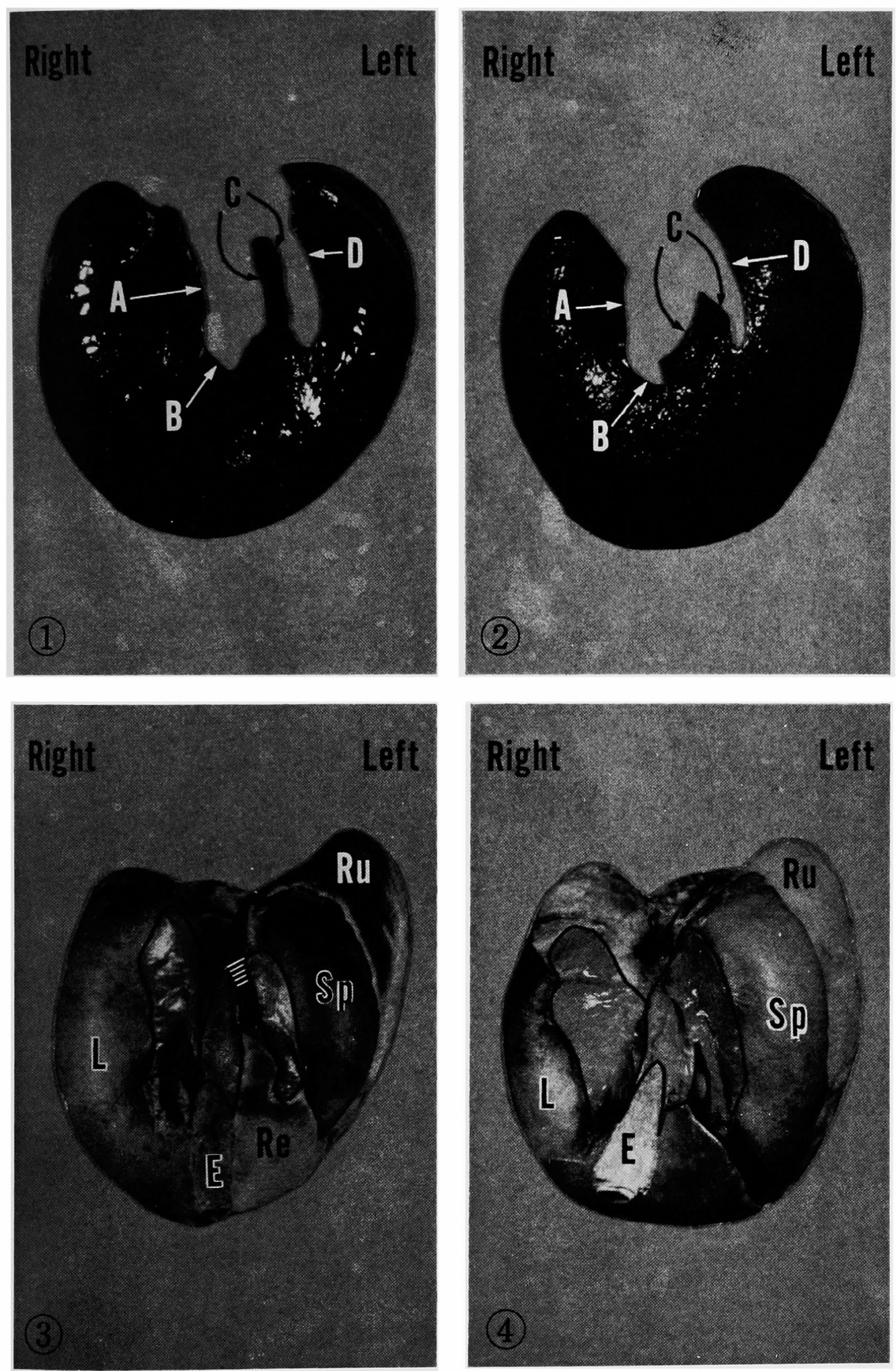

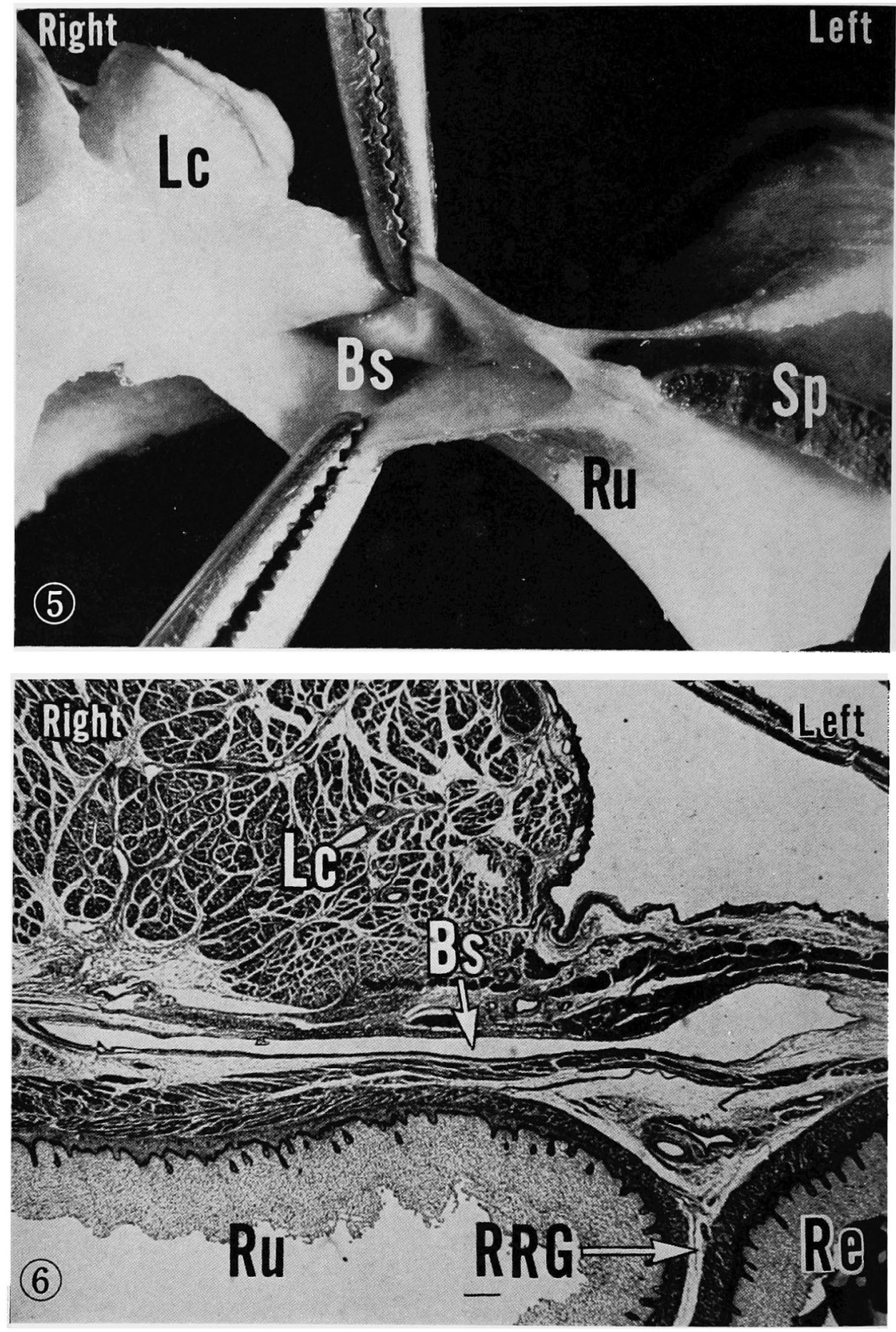

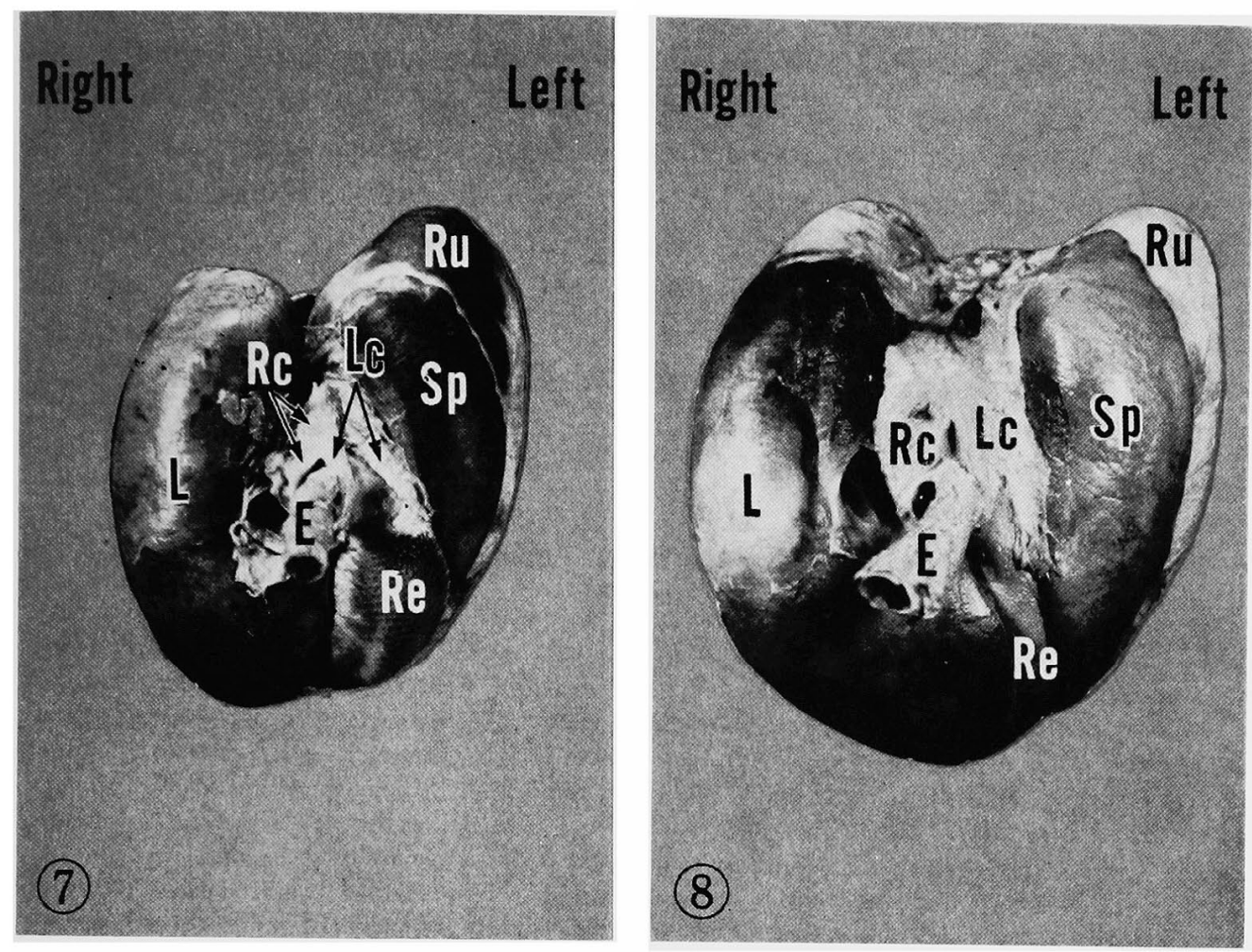

\section{Right}

Left

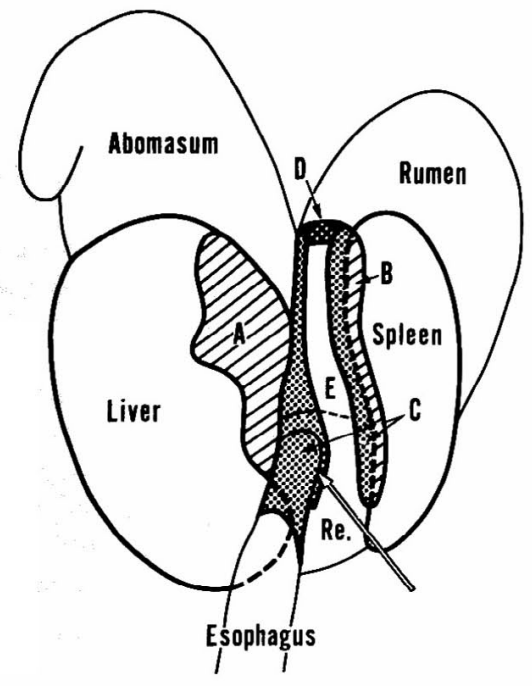

Fetus

(9)

Right

Left

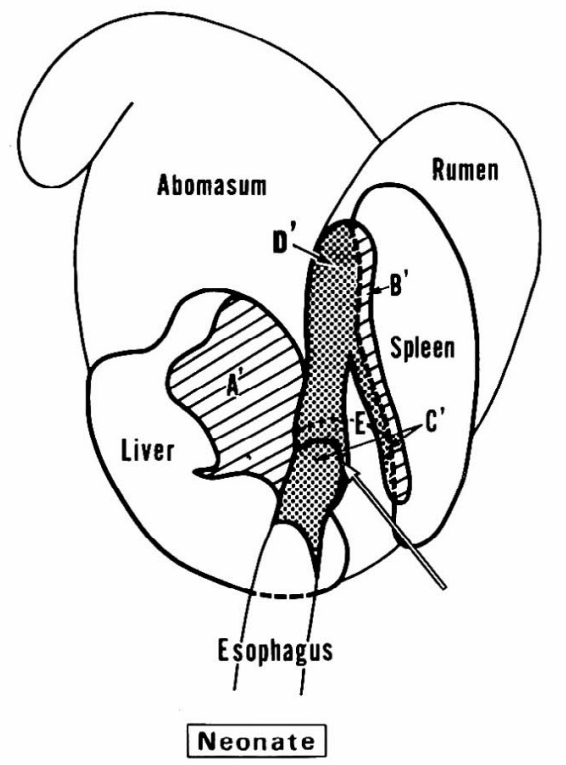

(10) 
hardened, the organs such as the esophagus, stomach, liver and spleen were removed en bloc together with the diaphragm, washed by running water and subjected to observation of the areas and extent of attachment of the diaphragm to these viscera.

Some animals were used for producing resin-casts of the alimentary canal and of both the thoracic and the abdominal cavities. Synthetic resin was injected into the thoracic cavity on either side and into the abdomen. Then, resin was injected into the esophagus through a catheter introduced beforehand. Resin to be injected had been colored differently, yellow for the thoracic cavity, green for the abdominal cavity and red for the alimentary canal, in order to differentiate each resin-cast at the time of observation. After polymerization and hardening were completed, the resin-cast of

\section{Explanation of Figures}

Fig. 5. Mácroscopic specimen cut frontally at the dorso-caudal end of diaphragmatic attachment to the abdominal organs of a fetus of $25 \mathrm{~cm}$ in C. R.L., showing a blind tunnel-like flat space (Bs) located beneath a thin membranous part of the diaphragm (pinched upward). This space is lined by a sercus membrane on its wall, lower part of which belongs to the dorsal sac of rumen (pinched downward). Muscular tissues from the left crus (Lc) of the diaphragm are wide in distribution as seen in this picture; they expand on the right dorsal surface (left side to the viewer) of the corsal sac of rumen and onto the left dorsal surface (right side to the viewer) of the dorsal sac of rumen $(\mathrm{Ru})$ to reach the spleen $(\mathrm{Sp}) . \times 14$.

Fig. 6. A histologic section through the part with a blind tunnel-like flat space (Bs) of a newborn calf of $98 \mathrm{~cm}$ in C.R. L. This section is slightly obliquely cut to show a part of the ruminoreticular groove (RRG) and a part of the reticulum (Re) on the right bottom of this figure. The blind space (Bs) is lined with a serous membrane continued from the abdominal cavity. Lc, the left crus of the diaphragm; $\mathrm{Ru}$, the cranial part of the dorsal sac of rumen. Stained with Heidenhain's Mallory azan variant. $\times 15$.

Fig. 7. Dorso-frontal view of formalin-hardened specimen from which the attached areas of the disphragm were removed to show the right and left crura of the diaphragm. A fetus of $25 \mathrm{~cm}$ in C.R. L. The right crus ( $\mathrm{Rc}$ ) is thicker than the left, distributing its muscular bundles to the liver and to the cardiac region. The left crus $(\mathrm{Lc})$ is thinner with wider distribution of its muscular bundles than the right. The muscular bundles reach the cardiac region as well as the reticulum (Re). E stands for the caudal end of esophagus and the cardiac region. $\times 0.8$,

Fig. 8. Dorso-frontal view of formalin-hardened specimen from which the attached areas of the diaphragm were removed. A newborn calf of $102 \mathrm{~cm}$ in C. R. L. Regions of distribution of muscular bundles from the both crura of the diaphragm are further expanding. For labelled abbreviations, refer to Fig. $7 . \times 0.3$.

Fig. 9. Schematic representation of a dorsal view of the areas of the diaphragm attaching to the abdominal organs in bovine fetuses. The attached areas are shown by alphabets. A, the area attached to the liver; $B$, the area attached to the spleen; $C$, the area of inverted- $V$ shape, the right limb of which shows the attached area to the cardiac region and to the right dorsal surface of the dorsal sac of rumen and the left limb of which shows the attached area to the left dorsal surface of the dorsal sac of rumen and to the dorsal surface of the reticulum; D, a very thin membrane of the diaphragm. A white arrow shows the junctional area of the esophagus and the cardia.

Fig. 10. Schematic representation of a dorsal view of the areas of the diaphragm attaching to abdominal organs in newborn calves. The attached areas are shown by alphabets with dashes. $A^{\prime}-D^{\prime}$ are corresponding to $A-D$ in Fig. 9 respectively. Note widening and thickening of the connected part shown by $\mathrm{D}^{\prime}$. A white arrow shows the junctional area of the esophagus and the cardia. 
the thoracic cavity on either side was first taken out. Then, the casts of the abdominal cavity and of alimentary canal were taken out en bloc with the diaphragm, liver and spleen. After removal of the cast of abdominal cavity, the diaphragm was severed along the edge of attachment to the abdominal viscera in a manner of leaving those areas attaching to the viscera in situ which were then colored blue on the side facing the thoracic cavity.

\section{Observations}

Frontal view of the cast of abdominal cavity

Fetus: With a frontal view of the cast of abdominal cavity after removal of the viscera, the attached area of the diaphragm to the surrounding organs appeared like a W-shaped space as shown in Fig. 1. The edge on the right side of this space (A in Fig. 1) showed the margin of attachment of the diaphragm to the liver. The edge seen at the right bottom and in part along the base of the right side of the central pillar of the $\mathrm{W}$-shaped space represented the margin of attachment of the diaphragm to the caudal end of esophagus and to the cardia (B in Fig. 1). The edge on either side of the central pillar represented the margin of attachment to the rumen ( $C$ in Fig. 1). This means that the central pillar of this W-shaped space was located between the attachment to the right dorsal surface and that to the left dorsal surface of the dorsal sac of rumen. The edge on the left side represented the margin attaching to the spleen (D in Fig. 1).

Neonate: The margin of attachment of the diaphragm to the abdominal viscera was traced roughly a line of $\mathrm{W}$ as it was in fetuses (Fig. 2). The way of attaching of the diaphragm to the abdominal viscera was essentially about the same as in fetuses except for the shortening of the central pillar of W-shaped space as compared with that seen in fetuses. The right side of this pillar showed the attachment to the right dorsal surface of the dorsal sac of rumen to reach the cardiac portion. The left side of this pillar represented the attachment to the left dorsal surface of the dorsal sac of rumen.

Frontal view of formalin-fixed abdominal viscera leaving the attached areas of the diaphragm in situ

Fetus: As shown in Fig. 3, an area on the right side (painted blue in the original specimen) showed a part of the diaphragm attaching to the liver. An area located in the center was a part attaching to the alimentary organs including the caudal end of esophagus, the cardiac region, the cranial sac of rumen and the right dorsal surface of the dorsal sac of rumen. A slender area on the left side represented a part of the diaphragm attaching to the left dorsal surface of the dorsal sac of rumen to reach the dorsal surface of the reticulum across the ruminoreticular groove as well as the spleen. Between the dorso-caudal ends of both the central and left areas, there was a thin membrane consisting of loose connective tissue and connecting the both areas. Although this thin membrane seemed to be a part of the diaphragm, we had cut it off. Thus, the area in the center and that in the left were continuous with each other at 
their caudal ends, forming a shape together like inverted V (refer to Fig. 9). Between the area located in the center (the right limb of this inverted $V$ ) and that in the left (the left limb of inverted V), a part of the abdominal cavity was engulfed as a blind flat space. When this part of blind flat space was cut through perpendicularly with surrounding tissues and seen from the frontal side, the blind space was clearly found to be a continuation of the abdominal cavity (Fig. 5). In order to see this part histologically, specimens were cut out, embedded in paraffin, and sectioned with a microtome. The sections were stained with hematoxylin-eosin or HeIDENHain's MaLLORY azan variant. Thus, histologic examination also revealed that this flat blind space was a continuation of the abdominal cavity, lined on its wall by a serous membrane with conenctive tissues (Fig. 6).

Neonate: Fundamentally, the frontal view of formalin-hardened viscera was almost similar to that in fetuses. However, the areas located in the center and in the left were connected clearly at their dorso-caudal ends with thick muscular tissue of the diaphragm, forming an inverted V-shape which was more clearly seen than that seen in fetuses (Fig. 4). Between the both limbs of this inverted V-shaped area, a part of the abdominal cavity was located in a manner of being engulfed, though far short in depth compared with a similar space in fetuses.

Frontal view of the specimens from which the attached areas of diaphragm were removed

The areas of the diaphragm attached to the abdominal viscera (painted blue in the original) were carefully removed by observing distribution of muscular fibers from the both crura of the diaphragm. After removal of the areas, the left and right crura of the diaphragm were clearly seen.

Fetus: The right crus was in contact with the diaphragmatic surface of the liver as well as with the caudal end of esophagus and the cardia at its ventral tip (Fig, 7). The right crus gave off muscular fibers to surround the caudal end of esophagus and the cardia. The left crus was smaller and appeared to be in contact with the left surface of the posterior mediastenum at its ventral tip. The left crus gave off muscular fibers to the dorsal surface of the dorsal sac of rumen and to the spleen, and also some fibers to the cardiac region.

Neonate: The right crus of the diaphragm was also in contact with the surface of the liver. The right crus expanded its contact not only to the esophagus-cardiac region but also to the right surface of the posterior mediastenum (Fig. 8). On the other hand, the extent of contact of the left crus with surrounding organs appeared markedly widened compared with that in fetuses in such a manner that the left crus enlarged to be in contact with the dorsal surface of the dorsal sac of rumen, with a part of the cranial sac of rumen and with the right side of the spleen. Muscular fibers from the left crus were further developed into thick bundles and layers. They also extended to the caudal end of esophagus and the cardiac region in association with those coming from the right crus. 


\section{Discussion}

The crura of the diaphragm in the cattle showed a peculiar development. The right crus was thicker than the left. Its muscular fibers extended onto the diaphragmatic surface of the right lobe of the liver, and also to the caudal end of esophagus and the cardia. The left crus was thinner but wider in its distribution than the right. Its muscular fibers expanded to the cardiac region, to the cranial sac of rumen, to the dorsal surface of the dorsal sac of rumen, and finally to the spleen. The fact that the muscular fibers, particularly of the left crus, expand onto the cranial sac as well as onto the dorsal sac of rumen leads us to think of a great and important role of the left crus in rumination. Such a wide distribution of muscular fibers from the diaphragmatic crura cannot be found in any of other non-ruminating domestic animals"6), suggesting a strong relation between the bovine diaphragm and MARTIN's "caudal esophageal sphincter" " proper to the bovine esophagus.

To the liver, the area of attachment of the diaphragm was restricted onto the diaphragmatic surface of the right lobe of the liver both in fetuses ( $A$ in Fig. 9) and in neonates ( $A^{\prime}$ in Fig. 10). The area was narrower and more slender in fetuses than that in neonates in which it expanded to form a round shape.

To the spleen, the area of attachment of the diaphragm was very slender along the right edge of the spleen, with little difference in extent between fetuses and neonates (cf. B in Fig. 9 and B' in Fig. 10).

The areas of attachment to the alimentary canal were shown as $\mathrm{C}$ and $\mathrm{C}^{\prime}$ in Fig. 9 and 10 schematically.

In fetuses, the areas appeared as two parallel limbs the caudal ends of which were connected with a very thin membrane (D in Fig. 9) presumably of the diaphragm, showing an inverted $\mathrm{V}$-shape. The right limb cranially extended to attach to the caudal end of esophagus together with the cardia in association with muscular fibers coming from the right crus of the diaphragm. The right limb also extended backward to a part of the dorsal side of the cranial sac of rumen and to the right dorsal surface of the dorsal sac of rumen. The left limb cranially attached to the dorsal surface of reticulum, extending backward across the ruminoreticular groove to the left dorsal surface of the dorsal sac of rumen to terminate at the right edge of the spleen. Between these two limbs, a part of the abdominal cavity was engulfed as a flat blind space provided with a white serous wall ( $E$ in Fig. 9).

In neonatal calves, the areas of attachment to the alimentary organs were clearly seen as a more enlarged inverted V-shape. Also, the dorso-caudal connecting part of both left and right limbs of this V-shape was considerably widened. Beneath this bridge-like connecting part was located a large majority of the area, which is called "Collum ruminis" (Atrium ventriculi, Vestibulum et Atrium ruminis) by MARTIN and SCHAUDER ${ }^{3 \text { ) }}$ and "Schleudermagen" (Atrium ruminis) by NICKEL et al.". The blind space of the abdominal cavity was located here also in the neonates, though the shape turned from flat to triangular with a frontal view. 
Thus, the blind space of abdominal cavity engulfed between the both limbs of the $\mathrm{V}$-shaped-attached area seemed to be reduced in its extent with the growth of the animal as illustrated in Figs. 9 and 10. However, Atrium ruminis, which was located ventrally to the blind space, always escaped from the attachment of the diaphragm by the existence of this tunnel-like blind space. This fact may be of a special interest for the physiologic behavior of rumination characteristic of species belonging to Ruminantia.

\section{Acknowledgement}

The authours wish to express their sincere gratitude to Dr. Kiyoshi Mrki and all members of the Tama Meat Inspectors Station for their kind help in collecting bovine fetuses.

\section{References}

1) Nickel, R., A. Schummer und E. Seiferle, Lehrbuch der Anatomie der Haustiere. Bd. 2, 147-169. Paul Parey, Berlin-Hamburg. 1960.

2) Ellengerger, W. und H. Baum, Handbuch der vergleichenden Anatomie der Haustiere. 18th ed., 271-275 and 282-283. Springer-Verlag, Berlin-Heidelberg. 1974.

3) Martin, P. und W. Schauder, Lehrbuch der Anatomie der Haustiere. Bd. 3, II Hälfte. Verdauung und Atmungsapparat der Hauswiederkäuer. 144-187. Verlag von Schidchardt \& Ebner, Stuttgart. 1935.

4) Kuramoto, S., Acta Medicina (Igaku Kenkyû), 29: 1290-1313. 1959. (in Japanese with English summary)

5) Matsur, T., Acta Anat. Nippon., 35: 15-38. 1960. (in Japanese with English summary)

6) Sisson, S. and J. D. Grossman, The Anatomy of the Domestic Animals. 4th ed., 404, 511, 514,1269 and 1511. 1953.

\section{牛胎仔および新生仔における獚隔膜の腹腔臟器, とくに胃に刘する付着領域について \\ 深谷幸作・金子家敏・浅利昌男 \\ 江口保暢・鹿野㭌 \\ 麻布獣医科大学家畜解剖学教室, 相模原市 229}

\begin{abstract}
反知類においては，腹腔蔵器に対する横隔膜の付着椂 式は，反擝に大きな意味を持つるのと思われる．本研究 においては，牛胎仔执よび新生仔を用い，とくに胃に対 する付着涨式定ホルマリン固定した材料および胸腔・腹 腔ならびに消化管への合成樹脂注入鋳型標本を観察する ことによって調べた，横隔膜と食道㧍よび胃との接着部 では，食道尾側端および噴門部の表面には主として右脚 加ら筋線維怔分布していた，胃に対する主店付着は左脚 からの筋線維によるものであった，胃に対する横隔膜の 付着領域は，前方よりみて逆V型定示す。この逆V型它 形成吉る左右雨板のう方右板は，在脚分らの筋線維とと

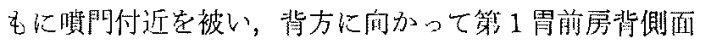
日畜会報, $50(11) ： 811-820$
\end{abstract}

から第 1 胃背藏右側背縁に至っていた この逆V型の左 板は第 2 胃背面より後方に向加、，第 1 胃背露左側背縁 および脾藏に至っていた，両板の背後側端における連結 部は，胎仔においては非常に薄く，新生仔に至って厚 く、広く、強鞄となった，これらの両板の閒扰よび橋状 の連結部の下には，疎性の結合組織を伴なった漿膜に被 われた盲管状の空隙があり，それによってその下に位置 するいすゆる NrckEL et al. のいう Schleudermagen は 常に横隔膜への付着から遊離していた，以上の観察結果 は反習機棈の考究に一つの参考所見として役立つである う.

日畜会竍，50(11)：811-820，1979 